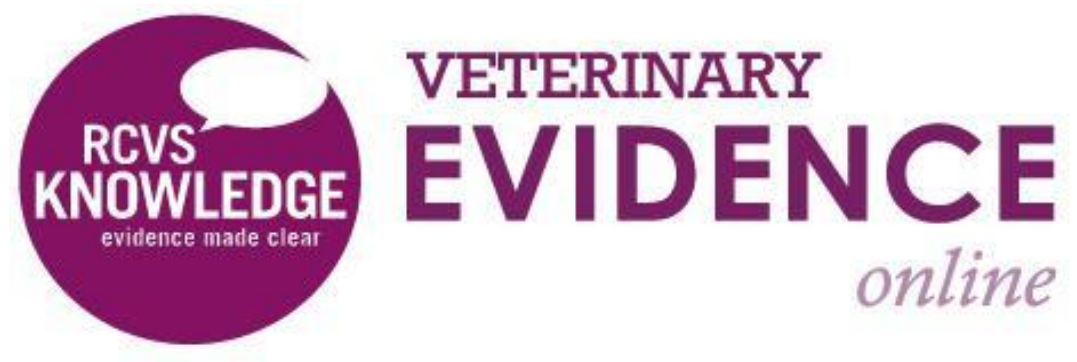

\title{
Does the Use of Lidocaine in Dogs and Cats Reduce Post-Operative Tracheitis?
}

A Knowledge Summary by

Erik Fausak MSLIS, MA, CVT, LVT, RLAT ${ }^{{ }^{*}}$

Kirsten Soules ${ }^{1}$

\footnotetext{
${ }^{1}$ Bel-Rea Institute of Animal Technology,1681 S Dayton St, Denver, CO 80247, USA

*Corresponding Author (efausak@gmail.com)
}

ISSN: 2396-9776

Published: 03 Feb 2017

in: Vol 2, Issue 1

DOI: http://dx.doi.org/10.18849/ve.v2i1.61

Reviewed by: Matyas Liptovszky (DVM, MSc, MRCVS) and Bruce Smith (BVSc MS FANZCVS DACVS) 


\section{KNOWLEDGE SUMMARY}

\section{Clinical bottom line}

Examination of a human systematic review and two veterinary prospective trials suggest topical application on the glottis, and placement of lidocaine on the endotracheal tube both seem to improve sore throat and laryngeal response in animals. Choice of pre-medicants and induction agents appears to have an impact on the extent of lidocaine efficacy. Consideration should be given in allowing enough time for lidocaine placement to have effect (around 60-90 seconds). Limitations in more confident assertions of the efficacy of lidocaine being utilized to prevent tracheitis is that only the human systematic review had enough follow up time to examine the benefits of lidocaine on sore throat in intubation.

\section{Question}

In dogs and cats, does the use of lidocaine lubricant on the endotracheal tube or placed on the glottis reduce tracheitis?

\section{Clinical Scenario}

At Bel-Rea Institute of Animal Technology, shelter pets are routinely neutered and lidocaine lubricant is applied to the cuff and tip of endotracheal tubes to reduce post-operative sore throat or tracheitis. Incidence of sore throat after surgery has not been evaluated at our institution. Additionally, lidocaine is utilsed in feline intubation to reduce laryngospasm.

\section{The Evidence}

A systematic review in human medicine and 2 prospective veterinary studies were utilised.

\section{Summary of the evidence}

\begin{tabular}{|r|l|}
\hline \multicolumn{2}{|c|}{ Cassu (2004) } \\
\hline Sopulation: & 10 cats average weight 3kg (8 males, 2 females), healthy. \\
\hline Sample size: & 40 (crossover) \\
\hline Intervention details: & $\begin{array}{l}10 \text { cats underwent induction and intubation four times: Group GTI0 } \\
\text { was thiopental and intubation, Group GTIO+Lido was thiopental with } \\
10 \% \text { lidocaine sprayed on the glottis, Group Gprop was propofol and } \\
\text { intubation, Group GProp+LIdo had propofol and 10\% lidocaine } \\
\text { sprayed on the glottis. All lidocaine spraying occurred on the glottis } \\
\text { and the intubator waited 60-90 seconds before intubating. } 15 \text { days } \\
\text { elapsed between the four procedures. All animals were previously } \\
\text { sedated with acepromazine. }\end{array}$ \\
\hline Outcome studied: & $\begin{array}{l}\text { Respiratory, heart rate, pulse oximetry, number of intubation } \\
\text { attempts, cough reflex, occurrence of laryngospasm, degree of }\end{array}$ \\
\hline
\end{tabular}




\begin{tabular}{|r|l|}
\hline & Main findings: \\
\hline (relevant to PICO question): & $\begin{array}{l}\text { Lidocaine spray groups worked better with thiopental but no real } \\
\text { difference was seen between the propofol groups with lidocaine or } \\
\text { without. }\end{array}$ \\
\hline Limitations: & $\begin{array}{l}\text { No critical evaluation and lack of description of who induced } \\
\text { and who intubated, which could have made this a blinded } \\
\text { study. }\end{array}$ \\
- Highly subjective criteria of cough reflex without \\
interobserver reliability.
\end{tabular}

\begin{tabular}{|c|c|}
\hline \multicolumn{2}{|l|}{ Dyson (1988) } \\
\hline Population: & $\begin{array}{l}32 \text { healthy cats scheduled for elective surgery. No additional } \\
\text { information. }\end{array}$ \\
\hline Sample size: & 32 cats \\
\hline Intervention details: & $\begin{array}{l}\text { Cats were separated into } 4 \text { groups: } \\
\text { Group } 1 \text { Lidocaine IV. Not specified. } \\
\text { Group } 2 \text { 2\% lidocaine applied to larynx, larynx was reviewed after } \\
\text { induction. use of tuberculin syringe, with a } 20 \mathrm{~g} \text { catheter that had } \\
25 \mathrm{~g} \text { holes and the end sealed by heat. } \\
\text { Group } 310 \% \text { lidocaine aerosol (one "squirt") to larynx, larynx was } \\
\text { reviewed after induction. } \\
\text { Group } 4 \text { no lidocaine. Not specified } \\
\text { Intubation was attempted } 90 \text { seconds after groups } 1-3 \text { were given } \\
\text { lidocaine. One clinician intubated all animals. }\end{array}$ \\
\hline Study design: & Prospective, non-blinded, controlled \\
\hline Outcome studied: & $\begin{array}{l}\text { The following were evaluated by the intubating clinician: } \\
\text { Induction consideration } \\
\text { Amount of thiopental used for intubation } \\
\text { Amount of thiopental used for a smooth transfer to the inhalant } \\
\text { Laryngeal relaxation (only applied to groups } 2 \text { and 3) } \\
\text { Intubation consideration } \\
\text { Response (laryngospasm) } \\
\text { \# of attempts } \\
\text { \# of coughs } \\
\text { Tube size } \\
\text { Extubation influence } \\
\text { Evidence of complications during extubation. }\end{array}$ \\
\hline $\begin{array}{l}\text { Main findings: } \\
\text { (relevant to PICO question): }\end{array}$ & $\begin{array}{l}\text { Less laryngospasm with topical lidocaine than IV or no treatment. } \\
\text { Fewer efforts were made with both topical lidocaine } \\
\text { administrations. } \\
\text { Topical intubation allowed for larger Endotracheal tubes. }\end{array}$ \\
\hline
\end{tabular}




\begin{tabular}{|l|l|}
\hline Limitations: & - Same intubator, less interobserver reliability with subjective \\
& evaluations. \\
& - Not blinded. \\
& - Lidocaine $2 \%$ administration was complicated with a \\
& - Nodified catheter. \\
\hline & Not ET Tubes are lubricated \\
\hline
\end{tabular}

\begin{tabular}{|c|c|}
\hline 15) & \\
\hline Population: & Adult humans undergoing intubation. \\
\hline Sample size: & 1940 Adult Humans undergoing endotracheal intubation. \\
\hline Intervention details: & $\begin{array}{l}\text { Systematic review, study inclusion criteria: } \\
\text { Randomised control trials involving adult humans with varying } \\
\text { degree of lidocaine use in endotracheal intubation (IV, spray, on the } \\
\text { tube, in the cuff). } \\
\text { Databases searched were: } \\
\text { Cochrane Central Register of Controlled Trials (CENTRAL) } \\
\text { Medline, and Embase } \\
\text { Measurements used: } \\
\text { Visual Aanalogue Scale (VAS) of sore throat. } \\
\text { Follow up duration was } 12-30 \text { hours post-operative } \\
\text { Two authors independently evaluated studies, but were not blinded } \\
\text { to authors and institutions. } \\
\text { Intervention types: } \\
\text {-endotracheal cuff was inflated with lidocaine } \\
\text {-lubrication of distal end of endotracheal tube with lidocaine } \\
\text {-spraying the glottis with lidocaine } \\
\text {-IV lidocaine administration }\end{array}$ \\
\hline Study design: & $\begin{array}{l}\text { Systematic review with meta-analysis including } 19 \text { Randomised } \\
\text { Control Trials. }\end{array}$ \\
\hline Outcome studied: & $\begin{array}{l}\text { - } \text { Risk of sore throat } 12-30 \text { hours after intubation/surgery. } \\
\text { - Severity of sore throat } 12-30 \text { hours after intubation/surgery. } \\
\text { - Amount of negative results from lidocaine administration. }\end{array}$ \\
\hline $\begin{array}{l}\text { Main findings: } \\
\text { (relevant to PICO question): }\end{array}$ & $\begin{array}{l}\text { All approaches with lidocaine appear to have been beneficial to } \\
\text { prevent sore throat. } \\
\text { No toxicities were reported in the use of lidocaine. }\end{array}$ \\
\hline Limitations: & $\begin{array}{l}\text { Didn't mention what portion of lidocaine lube administration } \\
\text { included besides, "distal". Relevant information would include if } \\
\text { "distal" endotracheal tube includes application on the cuff. } \\
\text { All studies had unclear risk of bias and received a lower GRADE (Trial } \\
\text { evaluation criteria) score. }\end{array}$ \\
\hline
\end{tabular}


Veterinary appreciation of lidocaine's effect on post-operative sore throats is limited due to communication barriers between humans and other animals. Human research in some way provides greater advantage because patients could communicate the existence of sore throat after intubation, which occurs $30-70 \%$ of the time in Tanaka et al.'s (2015) study.

Veterinary study limitations for sore throat did not have a significant follow up time, to evaluate postextubation sore throat. Future research should have better follow up periods following lidocaine application. No veterinary study examines placement of lidocaine on the endotracheal tube.

Measurement of sore throat is another veterinary challenge because Visual Analogue Scales will not reliably work in determining severity of animal sore throats.

Despite the limitations in the quality of human research and surrogate outcomes measured in veterinary research, lidocaine by any route does seem to improve sore throat or laryngeal response with minimal toxicity concerns.

\section{Methodology Section}

\begin{tabular}{|r|l|}
\hline \multicolumn{2}{|l|}{ Search Strategy } \\
\hline $\begin{array}{r}\text { Databases searched and dates } \\
\text { covered: }\end{array}$ & Pubmed, VetMed Resource, and CAB Abstracts \\
\hline Search terms: & $\begin{array}{l}\text { Pubmed Sore Throat AND lidocaine AND intubation CABI and Vet } \\
\text { Med Resource: lidocaine AND intubation }\end{array}$ \\
\hline Dates searches performed: & 12 April 2016 \\
\hline
\end{tabular}

\section{Exclusion / Inclusion Criteria}

Exclusion: $\begin{aligned} & \text { Only systematic reviews and metanalysis were included from } \\ & \text { human medicine. }\end{aligned}$

Inclusion: Any relevant research with dogs, cats and systematic human reviews.

\begin{tabular}{|l|c|c|c|c|c|}
\hline \multicolumn{1}{|c|}{ Search Outcome } & $\begin{array}{c}\text { Number of } \\
\text { results }\end{array}$ & $\begin{array}{c}\text { Excluded - human } \\
\text { systematic reviews } \\
\text { only }\end{array}$ & $\begin{array}{c}\text { Excluded - } \\
\text { relevance and } \\
\text { species specific }\end{array}$ & $\begin{array}{c}\text { Excluded - } \\
\text { duplicates }\end{array}$ & $\begin{array}{c}\text { Total } \\
\text { relevant } \\
\text { papers }\end{array}$ \\
\hline NCBI PubMed & 158 & 157 & 0 & 0 & 1 \\
\hline $\begin{array}{l}\text { Thomson Reuters } \\
\text { Web of Science }\end{array}$ & 36 & 0 & 31 & 0 & 5 \\
\hline CAB Direct & 40 & 0 & 4 & 36 & 0 \\
\hline Total relevant papers when duplicates removed & & & & 3 \\
\hline
\end{tabular}




\section{CONFLICT OF INTEREST}

The authors declare no conflict of interest.

\section{REFERENCES}

1. Cassu, R.N. et al (2004) Effects of Topical Lidocaine in the Endotracheal Intubation in Cats. Ars Veterinaria, 20 (1), pp. 28-34.

2. Dyson, D.H. (1988) Efficacy of Lidocaine Hydrochloride for Laryngeal Desensitization: A Clinical Comparison of Techniques in the Cat. Journal of the American Veterinary Medical Association, 192 (9), pp. 1286-1288.

3. Tanaka, Y. et al. (2015) Lidocaine for Preventing Postoperative Sore Throat. The Cochrane database of systematic reviews, 7, p.CD004081. 


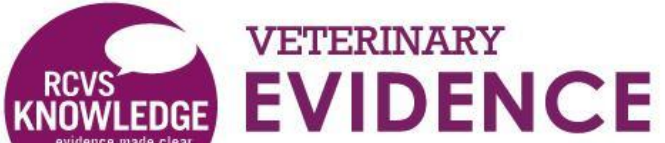 \\ ochese}

\section{Intellectual Property Rights}

Knowledge Summaries are a peer-reviewed article type which aims to answer a clinical question based on the best available current evidence. It does not override the responsibility

of the practitioner. Informed decisions should be made by considering such factors as individual clinical expertise and judgement along with patient's circumstances and owners' values. Knowledge Summaries are a resource to help inform and any opinions expressed within the Knowledge Summaries are the author's own and do not necessarily reflect the view of the RCVS Knowledge.

Authors of Knowledge Summaries submitted to RCVS Knowledge for publication will retain copyright in their work, but will be required to grant to RCVS Knowledge an exclusive license of the rights of copyright in the materials including but not limited to the right to publish, re-

publish, transmit, sell, distribute and otherwise use the materials in all languages and all media throughout the world, and to license or permit others to do so.

Authors will be required to complete a license for publication form, and will in return retain certain rights as detailed on the form.

Veterinary Evidence and EBVM Network are RCVS Knowledge initiatives. For more information please contact us at editor@veterinaryevidence.org

RCVS Knowledge is the independent charity associated with the Royal College of Veterinary Surgeons (RCVS). Our ambition is to become a global intermediary for evidence based veterinary knowledge by providing access to information

that is of immediate value to practicing veterinary professionals and directly contributes to evidence based clinical decision-making.

\section{www.veterinaryevidence.org}

RCVS Knowledge is a registered Charity No. 230886. Registered as a Company limited by guarantee in England and Wales No. 598443.

Registered Office:

Belgravia House

62-64 Horseferry Road

London SW1P 2AF 